\title{
PERBEDAAN IMPLEMENTASI TIPE DISCOVERY LEARNING TERHADAP KEMAMPUAN KOGNITIF, KETERAMPILAN FREE DISCOVERY, DAN PENGEMBANGAN KARAKTER KEMANDIRIAN SISWA SMP
}

\author{
Tunjung Paryana Karumikawati, S.Pd. ${ }^{1)}$ \\ Prof. Dr. Leny Yuanita, M.Kes. ${ }^{2)}$ \\ Prof. Dr. Endang Susantini, M.Pd. ${ }^{3)}$ \\ e-mail: super_girl11@ymail.com
}

1) Mahasiswa Pascasarjana Prodi Pendidikan Sains Universitas Negeri Surabaya

2) Dosen Pascasarjana Prodi Pendidikan Sains Universitas Negeri Surabaya

3) Dosen Pascasarjana Prodi Pendidikan Sains Universitas Negeri Surabaya

\begin{abstract}
The objective of this research is to compare the effectiveness of the guided discovery and the less structured discovery methods cognitive ability, free discovery skill, and autonomous character of the Junior High School. Forty Ponorogo Junior High School students have divided into two research classes were involved in this investigation using The Method of Science as the subject matter. The research was implemented in two phase, the development of the discovery learning resources, using the Kemp model, and the implementation of learning resources using the matching only pretest-posttest control group design (quasi experiment). From the hypothesis test ( $\alpha$ : 0,005) showed that: (1) Cognitive skill of less structured discovery class higher than guided discovery class (Sig. 0.0025< ). The individual cognitive skill of guided discovery students increased from $20 \%$ to $65 \%$, and for less structured discovery students increased from 10\% to 80\%; (2) Free discovery skill and autonomous character of less structured discovery class not higher than guided discovery class (free discovery skill Sig. 0,467>a; autonomous Sig.; 0,031; $0,028>a)$. Free discovery skill of guided discovery students increased from $20 \%$ to $80 \%$, and that of less structured discovery students increased from $10 \%$ to $35 \%$. The average percentage of autonomous character of guided discovery students ranges from $64,29 \%$ to $90,48 \%$, and that of less structured discovery students ranges from $71,43 \%$ to $90,48 \%$. The shortage of time allocation for the teaching and learning process was the main obstacle.
\end{abstract}

Key Words: discovery learning, cognitive ability, free discovery skills, autonomous character

\begin{abstract}
Abstrak: Penelitian ini bertujuan untuk membandingkan tipe pembelajaran discovery (guided discovery dan less structured discovery) terhadap kemampuan kognitif, keterampilan free discovery, dan kemandirian siswa SMP. Subjek penelitian sejumlah 40 siswa yang dibagi dalam 2 kelas penelitian di SMP Negeri 1 Ponorogo kelas VII dengan materi pembelajaran metode ilmiah. Penelitian dilaksanakan dalam dua tahap, yakni tahap pengembangan perangkat pembelajaran discovery mengikuti rancangan Kemp dan tahap penerapan perangkat pembelajaran menggunakan rancangan penelitian the matching only pretest-posttest control group design (quasi experiment). Hasil uji hipotesis ( $\alpha$ : 0,005) menunjukkan bahwa: 1) Kemampuan kognitif kelas less structured discovery lebih tinggi dari kelas guided discovery (Sig. 0,0025<a). Pada kelas guided discovery, kemampuan kognitif berdasarkan ketuntasan individu mengalami peningkatan dari $20 \%$ menjadi $65 \%$ dan pada kelas less structured discovery mengalami peningkatan dari 10\% menjadi $80 \%$. 2) Keterampilan free discovery dan kemandirian siswa kelas less structured discovery tidak lebih tinggi dari kelas guided discovery (keterampilan free discovery Sig. 0,467> $\alpha$; kemandirian Sig. 0,031; 0,028> ). Pada kelas guided discovery, keterampilan free discovery mengalami peningkatan dari $20 \%$ menjadi $80 \%$ dan pada kelas less structured discovery mengalami peningkatan dari $10 \%$ menjadi 35\%. Rata-rata persentase kemandirian pada kelas guided discovery bervariasi 64,29\% hingga 90,48\% dan kelas less structured discovery antara 71,43\% hingga 90,48\%. Waktu menjadi hambatan utama dalam penelitian ini sehingga dibutuhkan pengalokasian yang lebih baik pada setiap tahapan pembelajaran.
\end{abstract}

Kata-kata kunci: Discovery learning, kemampuan kognitif, keterampilan free discovery, kemandirian

\section{Pendahuluan}

Berbagai kebijakan telah dilakukan pemerintah Indonesia dalam meningkatkan mutu pendidikan umumnya dan pendidikan sains khususnya. Seperti yang tercantum pada tujuan utama ilmu pengetahuan dan teknologi yang termuat dalam Kurikulum Tingkat Satuan Pendidikan $(\mathrm{KTSP})^{[4]}$ yakni pencapaian dengan membudidayakan berpikir ilmiah secara kritis, kreatif dan mandiri. Depdiknas (2005) menyebutkan tujuan pembelajaran biologi memupuk sikap ilmiah yaitu jujur, objektif, terbuka, ulet, kritis dan dapat bekerjasama serta mengembangkan pengetahuan, keterampilan dan sikap percaya diri $)^{[4]}$.

Kemandirian merupakan salah satu karakter yang dapat diintegrasikan dalam pembelajaran. Hal ini terkait dengan kemandirian seseorang untuk dapat menyelesaikan masalah (life skills) dan mengambil keputusan dalam menentukan tindakan terhadap permasalahan yang ditemui setiap hari) ${ }^{[5]}$.

Menurut Bruner (1967), pembelajaran penemuan yang berbasis pada teori belajar konstruktivis, siswa berupaya memecahkan suatu masalah dalam situasi tertentu, melalui interaksi, eksplorasi dan manipulasi 
obyek, dengan pertanyaan dan kontroversi atau melakukan percobaan serta melakukan aktivitas kolaboratif dengan siswa lain. Dari aktivitas tersebut, siswa akan lebih mampu untuk mengingat konsep-konsep dan pengetahuan yang ditemukan.

Pembelajaran penemuan memiliki tiga tipe, yaitu guided discovery, less structured discovery dan free discovery. Diperlukan pembiasaan dalam aktifitas penemuan yang dapat dilakukan terlebih dahulu dengan pembelajaran tipe guided discovery sebagai pengenalan kemudian dilanjutkan dengan pembelajarann tipe less structured discovery untuk dapat mencapai free discovery. ${ }^{[1][3]}$

Pembelajaran discovery memberikan peluang luas bagi siswa untuk membangun pengetahuan dan melaksanakan problem solving, sehingga potensi intelektual mereka akan meningkat. Pembelajaran discovery dapat melatih keterampilan free discovery yang merupakan keterampilan proses serta mengkonstruksi afektif siswa dalam bersikap, khususnya melatih kemandirian dalam menyelesaikan masalah. ${ }^{[3]}$

Berdasarkan latar belakang, disiapkan perangkat pembelajaran yang direncanakan khusus untuk dapat mengembangkan karakter mandiri sebagai aspek afektif, sekaligus mampu meningkatkan kemampuan kognitif siswa khususnya mata pelajaran biologi. Penelitian bertujuan untuk membandingkan tipe pembelajaran discovery (guided discovery dan less structured discovery) terhadap kemampuan kognitif, keterampilan free discovery, dan pengembangan karakter kemandirian siswa.

\section{Metode Penelitian}

Penelitian dilaksanakan dua tahap, tahap pengembangan perangkat pembelajaran discovery mengikuti rancangan Kemp (1994) dan tahap implementasi perangkat pembelajaran discovery di kelas melalui the pretest-posttest control group design (quasi experiment). Adapun instrumen yang digunakan dalam penelitian meliputi lembar telaah perangkat pembelajaran, evaluasi, lembar penilaian kemandirian, lembar keterlaksanaan pembelajaran dan aktivitas siswa.

Selanjutnya data yang diperoleh dari instrumen, dilakukan uji hipotesis dengan ketentuan ${ }^{[7]}$ :

$$
\text { Hipotesis }=H_{0}: \mu 1 \geq \mu 2, H_{1}: \mu 1<\mu 2, \alpha: 0,05
$$

Uji hipotesis menggunakan t-test for independent sample untuk data yang terdistribusi normal dan homogen, serta uji u-mann whitney untuk data yang tidak terdistribusi normal atau tidak homogen dengan menggunakan program SPSS 17.0.

\section{Hasil Penelitian dan Pembahasan}

Melalui uji validasi perangkat dihasilkan perangkat pembelajaran yang terdiri dari silabus, RPP, LKS, evaluasi, lembar penilaian kemandirian, lembar pengamatan keterlaksanaan pembelajaran dan lembar pengamatan aktivitas siswa.

Berdasarkan hasil uji normalitas dan homogenitas data penelitian dengan bantuan SPSS 17.0, diperoleh informasi bahwa pada aspek kemampuan kognitif dan keterampilan free discovery asumsi dasar dalam menggunakan uji parametrik terpenuhi, yaitu data normal dan homogen, sehingga uji hipotesis dilakukan dengan menggunakan uji parametrik, yaitu dengan independent sample t-test. Sedangkan pada uji kemandirian yang ditinjau dari kognitif maupun afektif, salah satu asumsi dasar dalam menggunakan uji parametrik tidak terpernuhi, yaitu varians kedua kelompok tidak homogen, sehingga uji hipotesis dilakukan menggunakan uji non

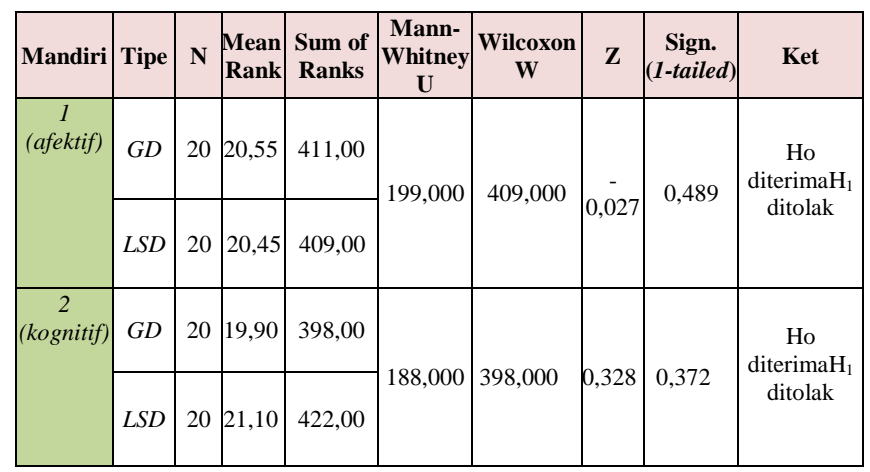

parametrik yaitu dengan U Mann-Whitney.

Untuk hasil uji hipotesis data menggunakan SPSS 17.0 terdapat pada Tabel 3.1 dan Tabel 3.2 berikut.

Tabel 3.1 Hasil Uji Hipotesis Parametrik Data Penelitian

\begin{tabular}{|c|c|c|c|c|c|c|c|}
\hline $\begin{array}{c}\text { Aspek yang } \\
\text { diamati }\end{array}$ & Tipe & $\mathbf{N}$ & Mean & $\begin{array}{c}\text { Std. } \\
\text { Deviation }\end{array}$ & $\mathbf{t}$ & $\begin{array}{l}\text { Sig. (1- } \\
\text { tailed })\end{array}$ & Ket \\
\hline \multirow[b]{2}{*}{$\begin{array}{c}\text { Kemampuan } \\
\text { kognitif }\end{array}$} & $\begin{array}{c}\text { Guided } \\
\text { discovery }\end{array}$ & 20 & 0,3740 & 0,28212 & \multirow[b]{2}{*}{$-2,961$} & \multirow[b]{2}{*}{0.0025} & \multirow{2}{*}{$\begin{array}{c}\text { Ho } \\
\text { ditolak, } \\
\mathrm{H}_{1} \\
\text { diterima }\end{array}$} \\
\hline & \begin{tabular}{|c|} 
Less \\
structured \\
discovery \\
\end{tabular} & 20 & 0,6110 & 0,22024 & & & \\
\hline \multirow{2}{*}{$\begin{array}{c}\text { Kemampuan } \\
\text { free } \\
\text { discovery }\end{array}$} & $\begin{array}{c}\text { Guided } \\
\text { discovery }\end{array}$ & 20 & 0,4010 & 0,29476 & \multirow[b]{2}{*}{1,150} & \multirow[b]{2}{*}{0,1285} & \multirow{2}{*}{$\mid \begin{array}{c}\text { Ho } \\
\text { diterima } \\
\mathrm{H}_{1} \\
\text { ditolak }\end{array}$} \\
\hline & \begin{tabular}{|c|} 
Less \\
structured \\
discovery \\
\end{tabular} & 20 & 0,2770 & 0,38166 & & & \\
\hline
\end{tabular}

Tabel 3.2 Hasil Uji Hipotesis Non Parametrik Data Penelitian Aspek Mandiri

Keterangan: $G D$ : guided discovery

LSD : less structured discovery

Hasil uji hipotesis kemampuan kognitif yang menerima $\mathrm{H}_{1}$, sejalan dengan apa yang diungkapkan oleh Carin (1993) tentang aktivitas berfikir siswa pada masing-masing tipe. ${ }^{[1]}$ Aktivitas berpikir yang dilakukan siswa kelas less structured discovery lebih tinggi 
dibandingkan kelas guided discovery. Sesuai dengan pernyataan Bruner (dalam Carin, 1993) "an individual learn and develops his or her mind only by using it", bahwa potensi intelektual seseorang akan berkembang hanya jika ia menggunakan potensi tersebut, hal ini berarti semakin banyak aktivitas berfikir yang dilakukan oleh seseorang maka potensi intelektualnya akan semakin tinggi. ${ }^{[1]}$ Potensi intelektual ini secara langsung berkaitan dengan tingkat pemahaman mereka terhadap materi, sehingga semakin tinggi aktivitas berfikir seseorang maka kemampuan kognitifnya akan semakin baik.

Pernyataan lain yang mendukung hasil penelitian diungkapkan oleh Marzano (2011) “Another aspect of enhanced discovery learning is allowing the learner to generate ideas about a topic along the way and then having students explain their thinking." [6] Jika pembelajaran penemuan ditingkatkan, memungkinkan pebelajar menggeneralisasikan ide-ide penting selama pembelajaran berlangsung dan memberikan kesempatan siswa untuk menjelaskan apa yang menjadi pemikirannya. Peningkatan pembelajaran penemuan dalam hal ini adalah pengurangan aktivitas pembimbingan oleh guru sehingga siswa lebih memiliki kesempatan untuk mengeksplorasi diri dalam kegiatan penemuan. Secara bertahap di kelas less structured discovery, aktivitas penemuan mengalami peningkatan dari guided discovery, less structured discovery dan free discovery. Akibatnya kesempatan siswa melakukan eksplorasi diri dan kemampuan menjelaskan juga meningkat.

Hasil uji hipotesis keterampilan free discovery yang menerima Ho, dipengaruhi oleh perbedaan tingkatan aktivitas berfikir siswa yang mana di kelas guided discovery pada level proses kognitif menerapkan (C3) sedangkan pada kelas less structured discovery pada level proses kognitif menciptakan (C6). Sehingga, keterampilan proses siswa kelas less structured discovery yang dilakukan siswa pada tipe ini lebih tinggi daripada tipe guided discovery.

Pada kelas guided discovery, pembimbingan yang intensif memberikan petunjuk yang jelas bagi siswa untuk menemukan strategi pemecahan masalah dengan benar. Seperti yang diungkapkan Sweller (2006) berikut, "Discovery Learning was Guided Instruction. Guided Instruction produced more immediate recall of facts than unguided approaches along with longer term transfer and problem-solving skills," (Kirschner, Sweller, Clark, 2006). ${ }^{[2]}$ Pemanduan atau pembimbingan menghasilkan pemanggilan kembali terhadap fakta-fakta lebih cepat daripada pembelajaran tanpa pembimbingan selama proses transfer dan keterampilan pemecahan masalah berlangsung. Namun, suatu waktu bisa dimungkinkan kemampuan eksplorasi siswa berkurang, karena siswa akan menggantungkan informasi dari guru atau pembimbing. Jika hal ini benar terjadi, kemampuan pemecahan masalah siswa akan rendah. Siswa mungkin bingung dalam usahanya mengembangkan pikiran ketika berhadapan dengan hal-hal yang abstrak, atau dalam usahanya menyusun suatu hasil penemuan dalam bentuk tertulis.

Pada kelas less structured discovery, pembimbingan yang dikurangi memberikan kesempatan yang lebih besar kepada siswa untuk mengeksplorasi diri, sehingga pada akhirnya siswa akan terbiasa menggunakan nalar dan logikanya untuk memecahkan permasalahan. Ungkapkan Bruner (1993), menunjukkan bahwa potensi intelektual seseorang akan berkembang hanya jika ia menggunakan potensi tersebut. ${ }^{[3]}$ Hal ini berarti jika semakin banyak keterampilan proses yang digunakan anak dalam aktivitas belajarnya maka aktivitas berfikir yang dilakukan oleh anak juga semakin tinggi sehingga berpengaruh pada potensi intelektualnya. Namun, eksplorasi bebas oleh siswa pemula dalam lingkungan belajar di kelas less structured discovery yang luas dapat memberikan tekanan pada siswa, bahkan membuat siswa frustasi karena tidak tahu apa yang harus dilakukan. Kondisi yang demikian menjadikan keterampilan siswa khususnya free discovery tidak maksimal.

Penelitian yang telah dilakukan selama bertahuntahun (Mayer, 2001; Paas, Renkl, \& Sweller, 1999, 2004; Winn, 2003) menunjukkan bahwa pebelajar akan memiliki memori beban kerja berat yang merugikan untuk belajar jika eksplorasi yang bebas di lingkungan yang kompleks ditugaskan kepada siswa khususnya bagi pebelajar pemula. ${ }^{[2]}$ Pebelajar akan kehilangan keterampilan yang diperlukan untuk mengintegrasikan informasi baru dengan informasi yang telah dipelajari di masa lalu. Hal ini juga dimungkinkan terjadi pada kelas less structured discovery.

Mayer (2004) berpendapat, "Unassisted discovery learning tasks do not help learners discover problemsolving rules, conservation strategies, or programming concepts. Pure discovery learning lacks structure in nature and hence will not be beneficial for the learner". [3] Tugas penemuan tanpa bimbingan belajar tidak membantu pelajar menemukan aturan pemecahan masalah, strategi konservasi, atau pemrograman konsep. Pure discovery kurang didukung strukturnya di alam, sehingga kurang tepat untuk pebelajar. Hal ini didukung hasil studi literatur dari tahun 1960an yang dilakukan Mayer (2004) menunjukkan bahwa, "in each case the empirical literature has shown that the use of pure discovery methods is not suggested". ${ }^{[2]}$

Hal lain yang dimungkinkan terjadi pada kedua kelas yakni terbatasnya waktu dalam kegiatan pembelajaran. Sesuai dengan pernyataan Carin (1993) ${ }^{[3]}$, diperlukan treatment guided discovery dalam waktu cukup lama sehingga siswa akan siap untuk menghadapi 
permasalahan ilmiah. Namun dalam penelitian, pelaksanaan pembelajaran terbatas hanya dalam 3 kali pertemuan sehingga treatment yang dilakukan kurang dapat meningkatkan pemahaman siswa terhadap keterampilan pemecahan masalah khususnya keterampilan proses dalam free discovery yang disajikan.

Hal yang dimungkinkan mempengaruhi hasil uji kemandirian yang menerima Ho adalah intensitas pembimbingan di kedua kelas. Pada kelas guided discovery, penyelesaian masalah oleh siswa masih mendapatkan bimbingan oleh guru sepenuhnya. Adanya pembimbingan yang terarah dan intensif yang dilakukan oleh guru mempengaruhi tingkah laku siswa yakni menjadi lebih terarah. Siswa cenderung mampu memposisikan diri dalam situasi yang benar dan tepat. Siswa menjadi tau apa yang harus dilakukan dengan cara yang benar karena pembimbingan memberikan informasi yang jelas kepada siswa. Yang harus ditekankan kepada para siswa adalah bahwa belajar mandiri bukan berarti belajar sendiri. Sering kali orang menyalahartikan belajar mandiri sebagai belajar sendiri. Kesalahpengertian tersebut terjadi karena pada umumnya mereka memandang belajar mandiri lebih pada pengertian belajar sendiri tanpa tutor atau teman belajar. Oleh karena itu, upaya menanamkan inisiatif dan kreativitas siswa dalam belajar merupakan faktor penting yang harus dilakukan guru. Dengan demikian, pembimbingan yang intensif oleh guru di kelas guided discovery ternyata dapat mengarahkan siswa menjadi lebih mandiri yang terarah.

Pada kelas less structured discovery, pembimbingan penyelesaian masalah oleh guru dikurangi, sehingga siswa harus berupaya lebih keras untuk dapat menyelesaikan permasalahan yang dihadapi. Taraf kemandirian yang dituntut di kelas less structured discovery cukup tinggi. Namun, pembimbingan yang dikurangi ternyata cukup berpengaruh pada kemandirian siswa. Kesempatan untuk belajar mandiri dapat diberikan dengan memberikan kebebasan dan kepercayaan pada anak untuk melakukan tugas-tugasnya. Namun demikian peran tutor dalam hal ini guru untuk mengawasi, membimbing, mengarahkan dan memberi contoh teladan tetap sangat diperlukan, agar anak tetap berada dalam kondisi atau situasi yang terarah dan aman. Hal ini menunjukkan bahwa kemandirian dikembangan dengan pembimbingan ideal untuk dapat mewujudkan siswa mandiri yang bertanggung jawab.

\section{SIMPULAN}

Berdasarkan deskripsi umum hasil penelitian tahap pengembangan perangkat dan pembahasan, dapat disimpulkan, yaitu:

1. Kemampuan kognitif siswa kelas VII pada materi metode ilmiah kelas less structured discovery lebih tinggi daripada kelas guided discovery.

2. Keterampilan free discovery dan kemandirian siswa kelas VII yang mengikuti pembelajaran less structured discovery tidak lebih tinggi dari siswa yang mengikuti pembelajaran guided discovery.

3. Pembelajaran discovery pada kedua yakni tipe less structured guided discovery dan tipe guided discovery terbukti dapat meningkatkan hasil belajar, melatih keterampilan free discovery dan karakter kemandirian siswa.

\section{DAfTAR PUStaka}

Abruscato, J.1996. Teaching Children Science: A Discovery Approach $4^{\text {rd }}$. Needham Heights. MA: Allyn and Bacon.

Anonim, tanpa tahun. Discovery Learning. Online:http://en.wikipedia.org/wiki/Discovery learning. Diakses 27 Agustus 2012.

Carin. A. A. 1993. Teaching Modern Sceience Sixth Edition. New York: Macmillan Publishing Company.

Depdiknas. 2005. Rencana Departemen Pendidikan Nasional Tahun 2005-2009. Jakarta: Depdiknas.

Kardi, S. tanpa tahun. Peran Life Skills dan Life Long Education Dalam Membina Sumber Daya Manusia. Makalah disajikan pada Seminar Nasional di Universitas Pendidikan Indonesia, Bandung.

Prince, M.J dan Felder, R.M. "Inductive Teaching and Learning Methods: Defenition, Comparison, and Research Bases". J. Engr. Education. Vol. 95, No. 2, pp. $123-138$.

Sugiyono, 2008. Metode Penelitian Pendidikan. Pendekatan Kuantitatif, Kualitatif dan R\&D. Bandung;

Alfabeta. 